\title{
CSR AND CONSUMER ATTITUDE ON BANKING INDUSTRY
}

\author{
Gëzim Simoni \\ University of Tirana, Faculty of Economy, Marketing Department, Tirana Albania \\ E-mail: gezim.simoni@yahoo.com
}

\begin{abstract}
This study aims to show the relationship that exists between corporate social responsibility and consumer attitude in the service industry. The focus of the study are CSR and banking industry in the context of Albania. The study clearly shows that there is a close relationship between corporate social responsibility and consumer attitude in the banking services industry. Corporate social responsibility influences the attitude of the consumer, CSR and our role in the success of organizations in the banking industry is considered important. CSR in banking industry in Albania is increasingly becoming a determining factor of consumer attitudes towards the services and organizations that offer them.
\end{abstract}

KEYWORDS: corporate social responsibility, consumer attitude, banking services.

\section{INTRODUCTION}

The industry of services and in particular the banking services industry in Albania has developed at high rates since 1990. Organizations part of the industry to cope with competition and achieve success, apply contemporary marketing practices. One of the practices of recent years applied by organizations is holistic marketing. Holistic marketing is one of the marketing practices in the continuation of developments and dynamics that the marketing field has had. According to Kotler \& Keller (2011), organizations design marketing activities that know the breadth. but also their interdependence. Based on this policy by the organizations everything in the field of marketing is important and at the same time there should be an integration of activities. Social responsibility marketing focuses on the activities of the organization that cares about the economic, legal, ethical and social perspective according to Carroll (1991). Marketing practices focused on social responsibility marketing have a growing trend and are considered to influence their success. Previous studies show a close link and the positive impact that social responsibility marketing has on consumer attitudes, Mohr, Webb and Harris (2001). The impact on consumer attitude through corporate social responsibility is one of the applied marketing practices. Evidence of the impact of corporate social responsibility on the consumer attitude in the banking services industry in Albania is the objective of the study.

\section{LITERATURE REVIEW}

Berger, I.E. Conninghom, P and Drumwright (2007) in their review article titled "Mainstreaming Corporate Social Responsibility: Developing Markets for Virtue" make the following observations. CSR is understood to be the way firms integrate social, environmental and economy concerns of their values, culture, decision making, 
strategy and operations with transparent and accountability and shout establish better practices within the firm, should create wealth and improve society at large.

The responsibility of business to society can be formed by a framework having four parts as economic, legal, ethical and discretionary (Caroll, 1979). These four areas of responsibility, which are required, expected or desired leads to the corporate social performance (CSP) of firms. In this definition, it is also suggested that CSR is not static, as society ${ }^{\text {ee }}$ expectation may differ across time and between societies. The discretionary aspect of CSR has been reframed as philanthropic component by Caroll in 1991.

At the base level is the economic responsibility/y . A company needs to survive and perform well economically first so that stakeholders like employees, shareholders and suppliers can be satisfied. A company on the next level needs to follow the legal requirements of its business environment in order to survive. This involves the paying of taxes and not breaking any laws and regulations of the land. The next step will be the ethical responsibility. The company should perform its activities ethically. These ethics could change from time to time. It could also vary according to cultures and some unique happenings or situations. Finally, the discretionary responsibility that a firm can participate is mostly charitable activities. On this pyramid it is the final two steps of ethics and discretionary actions that Corporate Social Responsibility policies play more of an influential part. It should be remembered that the activities here will affect stakeholder"s attitude towards a firm. A favourable view could increase profitability by increasing support from the customers and efficiency from the employees.

In its broadest sense, corporate responsibility represents a concern with the needs and goals of society which goes beyond the merely economic. Insofar as the business system as it exists today can only survive in an effectively functioning free society, the corporate social responsibility movement represents a broad concern with business's role in supporting and improving that social order (Eells \& Walton, 1974). Corporate social responsibility is the notion that corporations have an obligation to constituent groups in society other than stockholders. Two facets of this definition are critical. First, the obligation must be voluntarily adopted; behaviour influenced by the coercive forces of law or union contract is not voluntary. Second, the obligation is a broad one, extending beyond the traditional duty to shareholders to other societal groups such as customers, employees, suppliers, and neighbouring communities" (Jones, 1980).

CSR is a company's commitment to minimizing or eliminating any harmful effects and maximizing its long-run beneficial impact on society (Mohr, Webb, \& Harris, 2001). CSR refers to corporate actions that are conducive to societal welfare, above and beyond the companyes own interests or legal obligations (McWilliams and Siegel, 2001). Through their research they have identified that several companies have responded by increasing their Corporate Social Responsibility investments. However, some companies have resisted investing in Corporate Social Responsibility as they believe that it contradicts their aim to maximize profits if they invest in such projects. It is a conflict like situation amongst the companies. CSR is the commitment by a company to improve the welfare of its community by implementing certain 
discretionary practices and increasing the availability of its resources (Kotler and Lee, 2005).

Attitudes are defined as favorable or unfavorable feelings towards an object, (Katz 1960; Ajzen 2005). Where in the field of marketing and consumer behavior the object represents concepts such as products, advertisement, internet sites, prices, people, product uses, services, brands and issues, (Solomon 2009; Schiffman \& Kanuk 2004). Attitudes which cannot be directly observed need to be researched using measures on the subjects' positive or negative responses, verbal or behavioral. The measure can then illustrate their true attitudes towards the researched object, (Katz, 1960; Schiffman \& Kanuk 2004; Ajzen 2005). There exists a general belief among researchers that attitudes are not something an individual is born with, but rather learned through experiences and external influences such as friends, family and advertisements, (Schiffman \& Kanuk 2004; Solomon 2009). In the fields of psychology, economics and social behavior there have been interests in trying to predict behavior by analyzing attitudes, (Wilkie \& Pessemier 1973; Dick \& Basu 1994; Ajzen 2005). However, some researches have found that there are additional factors influencing behavior except for attitudes, such as social acceptance and authority, (Ajzen \& Fishbein 2005). One of the most famous examples of authority affecting behavior is the Milgram's test of obedience. The experiment was based on how far people would go as long as someone else told them what to do while additionally claiming that the person commanding them bore the responsibility of the outcome, (Milgram 1963).

Researchers have come to agree upon that attitudes are based on three different components, affect, behavior (conation) and cognition, (Breckler 1984; Schiffman \& Kanuk 2004; Ajzen 2005; Solomon 2009). Researchers have discussed that these three components of attitude also have a relationship with what market researchers call loyalty. As a function of an individual's relative attitude and repeated behavior being indications of loyalty toward a brand, (Dick \& Basu 1994). The component of affect refers to how an individual feels about the research object, (Schiffman \& Kanuk 2004; Solomon 2009). These feelings or emotions need to be researched using an assessment of the individual's emotions being favorable or not, using for example numerical research tools to scale from a positive feeling to a negative. The affect feelings are usually based on emotional experiences inside or in the vicinity of the research object, (Katz, 1960; Schiffman \& Kanuk 2004). E.g. if a customer is in a particular joyful mood when shopping inside a store, while having an already positive attitude toward the store, the positive reaction to the store will then be amplified. Behavior (Conation), the second component of attitudes is related to the behavior, or rather the intention to act in a specific behavior. Researchers then try and evaluate the tendency or likelihood of an individual acting in a particular way, (Katz, 1960; Schiffman \& Kanuk 2004; Ajzen 2005; Solomon 2009). Researchers try and measure conation by verbal questions to evaluate the customers' likelihood of e.g. purchasing a product or interest in a service, (Schiffman \& Kanuk 2004).

The final component of attitudes is cognition which is related to the individual's beliefs around the research object, (Katz, 1960; Solomon 2009). The beliefs are usually created by experiences or the individual's perceived knowledge of the object. The beliefs are 
centered on the attributes of the object. In research, the cognition of the customers' are identified by assessing attributes that are attractive and what attributes the customers' believe the object possesses, (Schiffman \& Kanuk 2004). The concept of the Tri component attitude model is that the three components of attitudes: affect, conation and cognition are interconnected. It describes the need that in order to understand the attitude of a consumer as to try and predict their behavior, all three components of the consumers attitude need to be investigated, (Schiffman \& Kanuk 2004). There exists a number of ways models to use in order to do so, often referred to as different variants of multi-attribute models, (Wilkie \& Pessemier 1973; Huber 1974; Bettman et al. 1975).

\section{METHODOLOGY}

This study is based on both primary and secondary data. The primary data of this study are collected from the sample customers in the study area to know the attitude of Customers about the CSR of banks. In this research primary data have been collected through specially designed questionnaire. The required secondary data has been collected from various publications like annual reports of individual banks, research papers published in journals on CSR, Banking and Finance, Magazines, books, reports of various banks and financial institutes.

\section{Data analysis}

Data for the study were collected by commercial banks operating in banking sector in Albania. The instrument used in this study is the questionnaire. Their selection was made taking into account the fact that the banking services take over the banks that were in the focus of the study. The most important attributes were determined through an organized survey and out of the 12 attributes part of the survey, seven of them turned out to be the most important attributes from the customers' point of view. All attributes listed in the survey reflected the element of corporate social responsibility in the banking services industry. The following questionnaire collected the results regarding the belief that these attributes are reflected as part of the activity in the banks surveyed. The Likert scale with its five levels was used to design the questionnaire so that consumers express their opinion on how much these attributes believe the two banks in the study from where they receive banking services. The results collected were processed based on the Fishbein Model. The study model is Fishbein of 1967, this is the basis of the multi-attribute model included in the models of other researchers such as, Shet (1970), Rosenberg (1956), Bass and Talarzyl (1972) and Fishbein (1975). Cronbach's Alpha coefficient was used to evaluate the reliability of the measures. According to the rule of thumb of Cronbach's Alpha coefficient (Zikmund, 2003), the reliability of data set is acceptable if Cronbach's Alpha is above 0.7. The resulting value is within the validity parameters considered. The questionnaire was designed in function of the model applied for the study using Likert scale with its five levels. 240 valuable study questionnaires were administered, from which the data were generated and statistically processed. The data obtained were analysed using the SPSS software. The applied model is the Fishbein Model which is widely used by field researchers in analogue studies in different countries. Corporate social responsibility is studied in its four components, economic, legal, ethical, and philanthropic. In this study, applying. Fishbein Model is assessed the impact of corporate social responsibility variables in 
consumer attitude. The object of the study is the impact of corporate social responsibility on consumer attitudes in the service industry and specifically in the banking services industry in Albania. The hypothesis raised is one: H1: Corporate social responsibility has a positive impact on consumer attitudes in the banking services industry. The context of the study is the banking services industry in Albania. The theoretical framework of the study is based on the evidence of the impact on the consumer attitude of corporate social responsibility. Corporate social responsibility is studied on the influence of its four constituent components.

\section{Implication to Research and practice}

The treatment of CSR and its various aspects is an important contribution for researchers, but also for organizations operating in the service sector and specifically in the banking services sector. CSR treatment offers the opportunity to researchers in the field and managers of organisms to identify the possible gap between customer expectations and perceptions of their expectations. CSR study, oriented organizations in the banking services industry can apply marketing practices that have a positive impact on the organization's position and achievement of objectives. The organizations that provide these services are constantly looking for factors that affect the customer's attitude and behavior. Identifying the factors that influence the attitude and behavior of bank service customers orients organizations to design the right strategies in achieving success. One of the marketing practices in the strategy of the banking services industry organizations is the holistic marketing practice and CSR as part of it.

\section{CONCLUSIONS}

The study clearly shows that there is a close relationship between corporate social responsibility and consumer attitude in the banking services industry. Corporate social responsibility positively affects the consumer attitude by affecting the success of organizations. Social and environmental issues in Albania are also turning increasingly into a determining factor of the consumer's attitude towards the services and organizations they offer. From the research it is clear the hierarchy of elements that constitute the practices of corporate corporate social responsibility evaluated from the consumer's point of view. The research shows that legal compliance in the activity of the service organization is the most important. Ethics or moral standards that guide the company in the exercise of activity is the second element in this hierarchy. Community support is the third element in the search hierarchy. These are the three elements that from corporate social responsibility practices influence the attitude of the consumer. Consumer attitude as a result of research is mainly influenced by these three elements and other elements listed at the hierarchical level. These three elements also constitute the most important attributes valued by consumers. The charitable activities element resulted in the fourth based on data analysis.

\section{Future Research}

Following the study regarding the impact of CSR on consumer attitude, as a marketing practice in the context of holistic marketing, the study of other holistic marketing practices and specifically the study of the impact of cause related marketing on 
consumer attitude in the banking services industry is a possible study of interest to both the organizations and the managers and decision makers.

\section{References}

Aaker, D. A. (1991). Managing Brand Equity. New York, NY: Free Press.

Ajzen, I. \& Fishbein, M., 1980. Understanding Attitudes and Predicting Social Behavior.

Ajzen, I., 2012. Martin Fishbein's Lecagy: The Reasoned Action Approach. The ANNALS of the American Academy of Political and Social Science , pp. 1128.

Berger, I.E. Conninghom, P. \& Drumwright, "Mainstreaming corporate social responsibility: Developing markets for virtue", California Management Review, Vol. 49, (4), pp.130, 2007.

Brown, T. J., \& Dacin, P. A. (1997). The company and the product: Corporateassociations and consumer product responses. Journal of Marketing,61(1), 68-84

Carroll, A. B. (1979). A three-dimensional conceptual model of corporate performance. Academy of Management Review, 4(4), 497-505.

Carroll, A. B. (1991). The Pyramid of Corporate Social Responsibility: Toward the Moral Management of Organizational Stakeholders. Business Horizons, 34(4), $39-48$.

Carroll, A. B. (1991). The pyramid of corporate social responsibility: toward the moral management of organisational stakeholders [Electronic version]. Business Horizons, July-August, 39-47.

Carroll, A. B. (1998). The four faces of corporate citizenship. Business and Society Review, 100/101, 1-7.

Cone Inc. (2004). Cone corporate citizenship study. Retrieved from http://www.coneinc.com.

Eells, R., \& Walton, C. (1974). Conceptual foundations of business (3rd ed.). Burr Ridge, IL: Irwin. Englewood Cliffs, NJ: Prentice-Hall .

Fishbein, M. (1963). An investigation of the relationship between beliefs about an object and the attitude toward that object. Human Relations, 16, 233-240.

Fishbein, M. (1967). A behavior theory approach to the relations between beliefs about an object and the attitude toward the object. In M. Fishbein (Ed.), Readings in attitude theory and measurement (pp. 389-400). New York: Wi

Fishbein, M., \& Ajzen, I. (1975). Belief, Attitude, Intention and Behavior: An Introduction to Theory and Research. Reading, MA: Addison-Wesley.

Jones, T. M. (1980). Corporate social responsibility revisited, redefined. California Management Review, 22(3), 59-67.

Kotler, P., \& Lee, N. (2005). Corporate social responsibility: doing the most good for your company and your cause. Hoboken, NJ: John Wiley \& Sons, Inc.

Kotler, Philip \& Keller, Kevin Lane, 2011. Marketing Management. 14th ed. New Jersey, USA: Pearson Education, fq.637

Mohr, L. A., \& Webb, D. J. (2005). The effects of corporate social responsibility and price on consumer responses. The Journal of Consumer Affairs, 39(1), 121-147. 
Mohr, L. A., Webb, D. J., \& Harris, K. E. (2001). Do consumers expect companies to be socially responsible? The impact of corporate social responsibility buying behavior. Journal of Consumer Affairs, 35(1), 45-72.

Mohr, L. A., Webb, D. J., \& Harris, K. E. (2001). Do consumers expectcompanies to be socially responsible? The impact of corporate socialresponsibility on buying behavior. The Journal of Consumer Affairs,35(1), 45-72.

Schiffman, L.G. Lazar Kanuk L. (1987).Consumer behavior (3rd ed).USA: PrenticeHall.

Sethi, S. P. (SPRING 1975). Dimensions of Corporate Social Performance: An Analytical Framework. California Management Review, Vol. 17 No. 3, (pp. 5864). 